vertebral pattern as the result of the operation of a creative force working according to plan, or it may have been produced from modified vertebræ by a process of evolution. In either event, the investigator is confronted with an abstraction beyond the means of verification. It is otherwise with the case of the intermaxillary bone. Here the 'metamorphosis' may be tested and observed in all its stages, and an evolutionary conclusion becomes not only possible but almost inevitable. But how did Goethe regard these two problems? To him their implications and significance were identical, and the only inference he drew from both of them was a confirmation of his theory of the common plan or idea. To such an outlook, deduction and induction are indistinguishable. Had the history of the intermaxillary bone suggested to his mind any conception of genetic relationships, he would surely have said so. Goethe therefore was a forerunner of Darwin only in the sense that before the historical continuity of species could be established it was necessary to formulate a doctrine of homologies, and in this important work Goethe played a leading part.

Not until the end of his life did Goethe exercise any appreciable influence on the biological thought of the period. This was due partly to delays in publication, but particularly to the imaginative and romantic character of his work-a quality rarely grateful to the academic mind. At first his influence was almost wholly reactionary, but the eclipse of Nature philosophy purged his writings of their ephemeral content and made it possible to form a sound judgment of the residue, with results that have only become evident in modern times. That his biological work will always command the respect and admiration of scientific men is a conclusion to which all his critics would assent.

\title{
Goethe's Reflections on Nature
}

$\mathrm{W}$ E reproduce below the translation of Goethe's reflections on Nature by T. H. Huxley, which was published as an introductory article to the first number of NaTuRE, dated Nov. 4, 1869. As originally printed, a casual reader might easily conclude that this lyrical composition was the work of Huxley himself, and in a letter to Dohrn, written shortly afterwards, he says: "It astonishes the British Philistines not a little. When they began to read it they thought it was mine, and that I had suddenly gone mad." Darwin himself was stirred to admiration, and wrote to Hooker as follows: "Lord, what a rhapsody that was of Goethe, but how well translated; it seemed to me, as I told Huxley, as if written by the maddest English scholar. It is poetry, and can I say anything more severe?" Huxley added to his translation some comments upon Goethe's " wonderful rhapsody on Nature which has been a delight to me from my youth up "; and he referred to it in an article entitled "Past and Present", contributed by him to the first issue of our fifty-first volume, on Nov. 1, 1894. In a footnote to this article, Huxley said: "A better translation than mine and an interesting account of the very curious obscurity which hangs about the parentage of Die Natur are to be found in Mr. J. Bailey Saunders' recently, published 'Goethe's Aphorisms and Reflections '."

\section{Nature: Aphorisms by Goethe *}

NATURE! We are surrounded and embraced by her : powerless to separate ourselves from her, and powerless to penetrate beyond her.

Without asking, or warning, she snatches us up into her circling dance, and whirls us on until we are tired and drop from her arms.

She is ever shaping new forms : what is, has never yet been; what has been, comes not again. Everything is new, and yet nought but the old.

We live in her midst and know her not. She is incessantly speaking to us, but betrays not her secret. We constantly act upon her, and yet have no power over her.

* From Nature, Nov. 4, 1869.

No. 3255, VoL. 129]
The one thing she seems to aim at is Individuality ; yet she cares nothing for individuals. She is always building up and destroying; but her workshop is inaccessible.

Her life is in her children ; but where is the mother ? She is the only artist; working-up the most uniform material into utter opposites; arriving, without a trace of effort, at perfection, at the most exact precision, though always veiled under a certain softness.

Each of her works has an essence of its own; each of her phenomena a special characterisation : and yet their diversity is in unity.

She performs a play; we know not whether she sees it herself, and yet she acts for us, the lookers-on.

Incessant life, development, and movement are in her, but she advances not. She changes for ever and ever, and rests not a moment. Quietude is inconceivable to her, and she has laid her curse upon rest. She is firm. Her steps are measured, her exceptions rare, her laws unchangeable.

She has always thought and always thinks; though not as a man, but as Nature. She broods over an allcomprehending idea, which no searching can find out.

Mankind dwell in her and she in them. With all men she plays a game for love, and rejoices the more they win. With many, her moves are so hidden, that the game is over before they know it.

That which is most unnatural is still Nature; the stupidest philistinism has a touch of her genius. Whoso cannot see her everywhere, sees her nowhere rightly.

She loves herself, and her innumerable eyes and affections are fixed upon herself. She has divided herself that she may be her own delight. She causes an endless succession of new capacities for enjoyment to spring up, that her insatiable sympathy may be assuaged.

She rejoices in illusion. Whoso destroys it in himself and others, him she punishes with the sternest tyranny. Whoso follows her in faith, him she takes as a child to her bosom.

Her children are numberless. To none is she altogether miserly; but she has her favourites, on whom she squanders much, and for whom she makes great sacrifices. Over greatness she spreads her shield.

She tosses her creatures out of nothingness, and tells them not whence they came, nor whither they go. It is their business to run, she knows the road. 
Her mechanism has few springs-but they never wear out, are always active and manifold.

The spectacle of Nature is always new, for she is always renewing the spectators. Life is her most exquisite invention; and death is her expert contrivance to get plenty of life.

She wraps man in darkness, and makes him for ever Iong for light. She creates him dependent upon the earth, dull and heavy ; and yet is always shaking him until he attempts to soar above it.

She creates needs because she loves action. Wondrous! that she produces all this action so easily. Every need is a benefit, swiftly satisfied, swiftly renewed.-Every fresh want is a new source of pleasure, but she soon reaches an equilibrium.

Every instant she commences an immense journey, and every instant she has reached her goal.

She is vanity of vanities; but not to us, to whom she has made herself of the greatest importance. She allows every child to play tricks with her; every fool to have judgment upon her; thousands to walk stupidly over her and see nothing; and takes her pleasure and finds her account in them all.

We obey her laws even when we rebel against them ; we work with her even when we desire to work against her.

She makes every gift a benefit by causing us to want it. She delays, that we may desire her; she hastens, that we may not weary of her.
She has neither language nor discourse; but she creates tongues and hearts, by which she feels and speaks.

Her erown is love. Through love alone dare we come near her. She separates all existences, and all tend to intermingle. She has isolated all things in order that all may approach one another. She holds a couple of draughts from the cup of love to be fair payment for the pains of a lifetime.

She is all things. She rewards herself and punishes herself ; is her own joy and ber own misery. She is rough and tender, lovely and hateful, powerless and omnipotent. She is an eternal present. Past and future are unknown to her. The present is her eternity. She is beneficent. I praise her and all her works. She is silent and wise.

No explanation is wrung from her ; no present won from her, which she does not give freely. She is cunning, but for good ends ; and it is best not to notice her tricks.

She is complete, but never finished. As she works now, so can she always work. Everyone sees her in his own fashion. She hides under a thousand names and phrases, and is always the same. She has brought me here and will also lead me away. I trust her. She may scold me, but she will not hate her work. It was not I who spoke of her. No! What is false and what is true, she has spoken it all. The fault, the merit, is all hers.

\section{Obituary}

Dr. G. Claridge Drtee, F.R.S.

$\mathrm{T}$ HE death on Feb. 29, at Oxford, of Dr. George Claridge Druce removes not only the best-known student of our British flora but also a remarkable personality. The charming story of his early life, which he has given us in the introduction to his "Flora of Buckinghamshire" shows how circumstances worked to shape his life and mould his character. He was born on May 23, 1850. The res angustae of his childhood threw him into the arms of Nature for his diversion, and his playthings were the wild flowers around the Northamptonshire village where his widowed mother had made her home. He tells how, by the lack of foresight of his guardian, he was debarred from a public school education, but the individuality which characterised his work through life, his independence, his undaunted persistence in arriving where others would have fallen short, may perhaps be traced to the less rigid training of his early years. In the woodlands near his home he studied the insect life as well as the plants, and by the age of fourteen had made a very representative collection of the local Lepidoptera; pupæ were dug for and larvæ bred, and plants were fixed in the memory by making carbon impressions of the leaves. Holidays spent in different localities in Bedfordshire on the greensand and chalk enlarged his knowledge of the flora and insect life.

At fifteen Druce was apprenticed to a large wholesale and retail chemist's business in Northampton, and two years later became actingmanager. The long business hours left little time for field-work, much of which was done by rising at 5.30 or 6 A.M. During the years that followed, without tutorial aid, he studied for and passed with honours the examinations for a pharmacentical chemist. A herbarium was indicated as part of the equipment of a pharmacist; in 1873 one was begun, and in the first year he collected about 750 species. He was now definitely working on the preparation of a "Flora of Northamptonshire", which was printed in 1879 in the Journal of the Northamptonshire Natural History Society, of which he was one of the founders and had also acted as honorary secretary and president. His last important piece of work was a much enlarged and fuller "Flora" of his native county, published in 1930 .

In 1879 Druce bought, with his savings, the pharmacy in High Street, Oxford, where he re. mained in business for the rest of his life. Prominent landmarks of subsequent years are the "Floras" of the Thames valley counties, at which he worked successively-Oxfordshire (1886), Berkshire (1897), and Buckinghamshire (1926). But the preparation of these county floras by no means represented the sum of his botanical work. No man had so intimate a personal knowledge of the British flora, which had been gained by frequent excursions to all parts of the country. The fact that a 'new' plant had been reported in Skye or some other locality, near or remote, was enough to send him hot-foot in search of it, and the Annual Reports of the Botanical Society and Exchange Club, which, as secretary, he has drawn up since 1904, are replete with new records and critical notes on British plants by himself and other botanists. The Botanical Society of the British Isles, which Druce started in 1908 as an appendage to the Exchange Club to enlist the help of well-wishers as well as of active workers, did

No. 3255 , Vol. 129] 